\title{
VIABILITAS INOKULAN DALAM BAHAN PEMBAWA GAMBUT, KOMPOS, ARANG BATOK DAN ZEOLIT YANG DISTERIL DENGAN IRADIASI SINAR GAMMA Co-60 DAN MESIN BERKAS ELEKTRON
}

\section{Viability of Inoculant in Peat, Compost, Coconut Shell Charcoal and Zeolite Sterilized by Gamma Irradiation Co-60 and Electron Beam Machine}

\author{
Sindy Marieta Putri'), Iswandi Anas'), Fahrizal Hazra') dan Ania Citraresmini3) \\ 1)Laboratorium Bioteknologi Tanah, Departemen Ilmu Tanah dan Sumberdaya Lahan, Fakultas Pertanian IPB \\ 2)Departemen Ilmu Tanah dan Sumberdaya Lahan, Fakultas Pertanian IPB, Kampus IPB-Dramaga Bogor \\ 3)Pusat Aplikasi Isotop dan Radiasi-Badan Tenaga Nuklir Nasional Indonesia, Pasar Jumat, Jakarta Selatan
}

\begin{abstract}
Carrier is one of the important factor to determine the quality of biofertilizer. The inoculant carriers should contain no or less microbial contaminant. The purpose of this research was to investigate viability of Azospirillum, Azotobacter and Phosphate Solubilizing Fungi inoculants in carrier material that were sterilized by Gamma Irradiation Co-60 and Electron Beam Machine (EBM). Each inoculants was injected to the sterilized peat, compost, coconut shell charcoal and zeolite. Viability of inoculants in steriled carrier was evaluated at 0, 7, 14, 42 and 70 days after preparation. The stirage was done in incubator at $25^{\circ} \mathrm{C}$. The result of viability of Azospirillum, Azotobacter and Phosphate Solubilizing Fungi inoculants on sterilized carrier material by Gamma Irradiation Co-60, EBM and autoclave tended to decline during storage 70 days at room temperature $\left(25^{\circ} \mathrm{C}\right)$. Viability of Azospirillum inoculants in zeolite sterilized by Gamma Irradiation Co-60 and autoclave gave the highest numbres of viable cells. Storage of these inoculants at $25^{\circ} \mathrm{C}$ for 70 days only reduce the number of viable cells by 11.1\%. Viability of Phosphate Solubilizing Fungi inoculants in coconut shell charcoal or compost sterilized by Gamma Irradiation Co-60 went down by $99.8 \%$ after 70 days. The sterilization of carriers by using autoclave or Gamma Irradiation Co-60 were better than EBM sterilization. .
\end{abstract}

Keywords: Carrier, Electron Beam Machine, Gamma Irradiation Co-60, sterilization, viability

\section{PENDAHULUAN}

Biofertilizer atau yang lebih dikenal dengan pupuk hayati merupakan salah satu alternatif pupuk yang dapat mengurangi ketergantungan penggunaan pupuk kimia. Pupuk hayati merupakan bahan yang mengandung sel hidup atau mikrob yang memiliki kemampuan untuk menambat nitrogen maupun melarutkan fosfat yang sukar larut (Rao, 1982). Penggunaan pupuk hayati memanfaatkan mikrob dalam mempercepat proses mikrobiologi untuk meningkatkan ketersediaan hara sehingga dapat dimanfaatkan oleh tanaman. Selain itu pupuk hayati mampu mengaktifkan serapan hara oleh tanaman, mempercepat proses pengomposan, memperbaiki struktur tanah, dan menghasilkan substansi aktif yang dapat meningkatkan pertumbuhan tanaman (Tombe, 2008).

Beberapa mikrob yang sering digunakan dalam pupuk hayati antara lain Azotobacter sp. dan Azospirillum sp. untuk menambat $\mathrm{N}_{2}$ dari udara tanpa harus bersimbiosis dengan tanaman. Ada juga Aspergillus sp. yang merupakan mikrob pelarut $\mathrm{P}$ yang sangat efektif dalam melepaskan ikatan $\mathrm{P}$ yang sukar larut. Keuntungan lain dari mikrob tersebut adalah peningkat ketersediaan hara serta pemantap agregat tanah. Berdasarkan penelitian Hidayati (2009), aplikasi pupuk hayati yang mengandung mikoriza dan bakteri penambat $\mathrm{N}$, bakteri pelarut $\mathrm{P}$ dan bakteri pelarut $\mathrm{K}$ terbukti telah meningkatkan pertumbuhan jagung.
Menurut Tombe (2008), salah satu faktor yang menentukan mutu pupuk hayati adalah kepadatan populasi inokulan yang ada di dalamnya. Ketahanan hidup (viabilitas) inokulan perlu dipertahankan dalam jumlah yang tinggi selama masa penyimpanan pupuk hayati. Hal tersebut dilakukan agar jumlah mikrob inokulan yang diberikan ke tanah lebih mendominasi mikrob indigenus di dalam tanah sehingga kualitas pupuk hayati mampu memberikan hasil yang optimum untuk pertumbuhan tanaman.

Inokulan dalam bahan pembawa merupakan kultur sediaan mikrob fungsional seperti Azospirillum sp, Azotobacter sp, Aspergillus sp dan lain-lain. Formulasi inokulan umumnya dipersiapkan dalam bentuk cair. Kekurangan dari formulasi cair tersebut adalah rendahnya viabilitas inokulan selama masa penyimpanan, sulitnya dalam hal pendistribusian, penyimpanan dan pengaplikasian di lapang (Van Dyke dan Prosser, 2000). Penggunaan bahan pembawa menjadi solusi untuk mengatasi kekurangan dari formulasi inokulan cair. Untuk itu bahan pembawa menjadi unsur yang penting dalam menentukan kualitas pupuk hayati karena diharapkan mampu mempertahankan viabilitas dan menjaga keefektifan mikrob inokulan selama masa penyimpanan.

Bahan pembawa yang umum digunakan berupa bahan organik seperti gambut, arang, kompos, zeolit dan sebagainya. Penginokulasian inokulan ke dalam bahan 
pembawa bertujuan untuk menyesuaikan lingkungan hidup mikrob inokulan sebelum diberikan ke tanah. Salah satu syarat bahan pembawa yang baik adalah steril dari mikrob indigenus sehingga inokulan mampu bertahan hidup tanpa adanya persaingan dengan mikrob indigenus dalam bahan pembawa.

Sterilisasi bahan pembawa merupakan tahap yang harus dilakukan sebelum penginokulasian. Pemilihan metode sterilisasi diperlukan agar bahan pembawa tidak mengalami kerusakan yang dapat mempengaruhi viabilitas inokulan. Metode sterilisasi bahan pembawa yang umum digunakan adalah metode fisik yaitu meliputi pemanasan, pengeringan dan radiasi. Metode sterilisasi pemanasan (panas lembab) biasanya menggunakan autoklaf yang memanfaatkan panas dalam suatu ruangan bertekanan dengan temperatur mencapai $121^{\circ} \mathrm{C}$ selama 60 menit. Autoklaf memiliki kekurangan yaitu menimbulkan kerusakan sifat kimia bahan pembawa dan menghasilkan unsur beracun. Menurut Toharisman (1989) intensitas sterilisasi tanah menggunakan autoklaf dapat meningkatkan kelarutan $\mathrm{Fe}$, Mn dan $\mathrm{Zn}$ yang tinggi sehingga dapat meracuni mikob yang ada di dalamnya.

Metode sterilisasi fisik lainnya adalah radiasi. Iradiasi Sinar Gamma Co-60 memanfaatkan gelombang elektromagnetik (sinar Gamma), sedangkan Mesin Berkas Elektron (MBE) memanfaatkan elektron berenergi tinggi untuk meradiasi bahan pembawa. Radiasi sinar Gamma atau elektron berenergi tinggi disebut juga radiasi pengion karena energi radiasi yang terserap oleh benda akan berinteraksi dengan benda tersebut dan menimbulkan efek biologi yang mengubah proses kehidupan normal dari sel hidup. Pada mikrob dapat berpengaruh terhadap DNA sehingga mikrob tidak dapat membelah diri akibat perubahan yang ditimbulkan oleh radiasi pengion (Hilmy, 1980).

Metode sterilisasi radiasi menggunakan dosis radiasi yang merupakan besaran energi yang diabsorbsi oleh suatu bahan. Dosis optimum ditentukan terlebih dahulu sehingga dalam penggunaannya mampu mematikan mikrob baik itu bakteri maupun fungi. Dosis serap (D) didefinisikan sebagai rata-rata energi yang diserap bahan per satuan massa bahan tersebut. Satuan yang digunakan saat ini adalah Gray (Gy) dimana 1 Gray $(\mathrm{Gy})=1$ Joule $\mathrm{kg}^{-1}$ sehingga diperoleh hubungan bahwa 1 Gray $(\mathrm{Gy})=100$ rad. Menurut Kume (2005), radiasi Sinar Gamma memiliki efektivitas yang berbeda dalam mematikan mikrob seiring dengan besaran dosis yang diberikan. Semakin besar dosis yang diberikan maka daya mematikan mikrobnya semakin besar pula.

Tujuan penelitian adalah mengevaluasi viabilitas inokulan Azospirillum, Azotobacter dan Fungi Pelarut Fosfat dalam bahan pembawa gambut, kompos, arang batok dan zeolit yang telah disterilisasi dengan metode iradiasi Sinar Gamma Co-60, MBE dan autoklaf selama masa penyimpanan.

\section{BAHAN DAN METODE}

\begin{tabular}{ccccc}
\multicolumn{2}{c}{ Penelitian dilaksanakan } & di & \multicolumn{2}{c}{ Laboratorium } \\
Bioteknologi Tanah Departemen & Ilmu Tanah dan
\end{tabular}

Sumberdaya Lahan, Institut Pertanian Bogor. Proses sterilisasi bahan pembawa menggunakan iradiasi Sinar Gamma Co-60 dan Mesin Berkas Elektron (MBE) dilakukan di Pusat Aplikasi Isotop dan Radiasi-Badan Tenaga Nuklir Nasional Indonesia (PATIR-BATAN), Pasar Jumat, Jakarta Selatan.

Bahan yang digunakan adalah bahan pembawa berupa gambut yang berasal dari Kalimantan Selatan; kompos yang diproduksi di BATAN; arang batok dan zeolit yang berasal dari Cikembar, Sukabumi (Jawa Barat). Isolat yang digunakan adalah Azospirillum, Azotobacter dan Fungi Pelarut Fosfat. Alat yang digunakan untuk sterilisasi bahan pembawa adalah iradiasi Sinar Gamma Co-60, MBE dan autoklaf.

\section{Persiapan Bahan Pembawa}

Masing-masing bahan pembawa dihaluskan hingga berukuran partikel $0.5 \mathrm{~mm}-1.5 \mathrm{~mm}$. Bahan pembawa terlebih dahulu dianalisis sifat kimianya untuk mengetahui karakteristik bahan. Pengukuran $\mathrm{pH}-\mathrm{H}_{2} \mathrm{O}$ dilakukan menggunakan $\mathrm{pH}$-meter dengan perbandingan sampel dan aquades sebesar 1:10. Pengukuran kadar air dilakukan melalui pengovenan dengan suhu $105^{\circ} \mathrm{C}$ selama 24 jam untuk mengetahui kelembaban bahan pembawa.

Masing-masing bahan pembawa dikemas ke dalam plastik sebanyak $10 \mathrm{~g}$. Hal ini bertujuan untuk memudahkan dan meminimalkan kontaminasi pada saat melakukan seri pengenceran. Bahan pembawa dikemas ke dalam plastik tahan panas untuk sterilisasi autoklaf. Sterilisasi iradiasi Sinar Gamma Co-60 dan MBE menggunakan plastik HDP (High Density Plastic) kemudian kemasan disegel dengan rapat menggunakan sealer.

\section{Proses Sterilisasi Bahan Pembawa}

Sterilisasi menggunakan autoklaf dilakukan sebanyak dua kali selama dua hari berturut-turut dengan suhu mencapai $121^{\circ} \mathrm{C}$ selama 60 menit. Hal ini bertujuan untuk memberikan jeda waktu spora berkecambah sehingga pada saat pemanasan berikutnya dipastikan semua mikrob dapat terbunuh. Bahan pembawa sebanyak $10 \mathrm{~g}$ dimasukkan ke dalam plastik tahan panas kemudian ditutup menggunakan klip. Setelah selesai proses autoklaf, uap air dalam plastik dibiarkan mengering kemudian disegel dengan rapat menggunakan sealer pada akhir proses autoklaf hari kedua.

Sterilisasi Iradiasi Sinar Gamma Co-60 dilakukan dengan cara sejumlah bahan pembawa, yang masingmasing telah dikemas dalam plastik HDP sebanyak $10 \mathrm{~g}$ per kemasan bahan pembawa, ditempatkan menjadi satu dalam satu wadah kontainer lalu diletakkan di dalam ruang radiasi atau irradiation chamber. Ruang radiasi tersebut kemudian diberikan sinar gamma yang berasal dari sumber radiasi. Sumber radiasi tersebut dikendalikan oleh operator dari ruangan yang berbeda. Dosis radiasi yang diberikan adalah $50 \mathrm{kGy}$ untuk semua sampel.

Bahan pembawa yang disterilisasi menggunakan MBE permukaannya diratakan kurang dari $1 \mathrm{~cm}$ pada saat diletakkan di wadah yang akan melewati MBE. Hal ini perlu dilakukan karena pada MBE hanya terjadi tumbukan 
radiasi pada permukaan bahan yang akan dipancarkan. Wadah tersebut kemudian masuk ke dalam ruang berkas elektron dengan jalur khusus yang akan melewati pancaran elektron. Sampel bahan pembawa dilewatkan di bawah mesin berkas elektron sebanyak 5 kali yang setara dengan dosis $50 \mathrm{kGy}$.

\section{Produksi Inokulan}

Isolat Azospirillum dan Azotobacter diperbanyak menggunakan $100 \mathrm{ml}$ Nutrient Broth kemudian dikocok selama tiga hari dengan kecepatan $120 \mathrm{rpm}$ pada suhu kamar. Fungi Pelarut Fosfat (FPF) diperbanyak menggunakan $100 \mathrm{ml}$ Pikovskaya cair yang dikocok selama tiga hari dengan kecepatan $120 \mathrm{rpm}$ pada suhu ruang setelah itu ditumbuhkan dalam media Potato Dextrose
Agar. Spora fungi yang tumbuh dalam media tersebut kemudian dipanen.

Penetapan populasi masing-masing inokulan dilakukan untuk mengetahui jumlah sel awal inokulan yang dimasukkan ke dalam bahan pembawa yang telah disterilisasi oleh iradiasi Sinar Gamma Co-60, MBE dan autoklaf. Hasil penetapan populasi inokulan Azospirillum, Azotobacter dan Fungi Pelarut Fosfat (FPF) dapat dilihat pada Tabel 1. Jumlah sel inokulan yang dimasukkan ke dalam bahan pembawa gambut dan kompos berbeda dengan jumlah sel inokulan yang dimasukkan ke dalam bahan pembawa arang batok dan zeolit. Hal tersebut terjadi karena produksi inokulan yang dilakukan berbeda sehingga hasil jumlah sel yang didapatkan berbeda pula.

Tabel 1. Jumlah sel inokulan Azospirillum, Azotobacter dan fungi pelarut fosfat yang dimasukkan ke dalam bahan pembawa

\begin{tabular}{ccc}
\hline Bahan Pembawa & Mikrob & Jumlah sel (spk ml $\left.^{-\mathbf{1}}\right)$ \\
\hline & Azospirillum & $1.40 \times 10^{7}$ \\
Gambut dan Kompos & Azotobacter & $9.56 \times 10^{8}$ \\
& $6.88 \times 10^{7}$ & $4.50 \times 10^{5}$ \\
Arang batok dan Zeolit & Fungi Pelarut Fosfat & $4.78 \times 10^{9}$ \\
& Azospirillum & $3.44 \times 10^{8}$ \\
\hline
\end{tabular}

\section{Proses Inokulasi}

Proses inokulasi Azospirillum, Azotobacter dan FPF ke dalam bahan pembawa dilakukan secara aseptik di laminar flow. Sebanyak $5 \mathrm{ml}$ inokulan dimasukkan ke dalam kemasan yang berisi $10 \mathrm{~g}$ bahan pembawa menggunakan jarum suntik setelah itu ditutup sehingga tidak memungkinkan terjadinya kontaminasi. Selanjutnya bahan pembawa dalam kemasan diratakan hingga homogen dan diberi label sesuai dengan nama bahan pembawa dan jenis inokulannya. Kemasan-kemasan bahan tersebut dimasukkan ke dalam kotak dan disimpan di dalam ruangan pada suhu kamar $\left(25^{\circ} \mathrm{C}\right)$.

\section{Uji Viabilitas Inokulan Selama Masa Penyimpanan}

Pengujian dilakukan selama masa penyimpanan dengan periode pengujian pada hari ke-7, hari ke-21, hari ke-42 dan hari ke-70. Uji viabilitas inokulan dilakukan dengan cara memasukkan satu kemasan bahan pembawa $(10 \mathrm{~g}) \mathrm{ke}$ dalam $90 \mathrm{ml}$ larutan fisiologis $(\mathrm{NaCl} 0.85 \%)$, kemudian dikocok selama 15 menit supaya larutan menjadi homogen dan setelah itu membuat seri pengenceran. Masing-masing inokulan ditumbuhkan pada media NFB untuk Azospirillum, NFM untuk Azotobacter dan
Pikovskaya untuk FPF lalu diinkubasi selama 3 hari untuk Azotobacter dan FPF, 14 hari untuk Azospirillum. Penghitungan koloni dilakukan setelah diinkubasi.

\section{HASIL DAN PEMBAHASAN}

\section{Uji Viabilitas Azospirillum dalam Bahan Pembawa Steril}

Viabilitas Azospirillum dalam bahan pembawa arang batok, zeolit, gambut dan kompos yang telah disterilisasi menggunakan metode sterilisasi yang berbeda (iradiasi Sinar Gamma Co-60, Mesin Berkas Elektron (MBE) dan autoklaf) hingga masa penyimpanan 70 hari pada suhu kamar $\left(25^{\circ} \mathrm{C}\right)$ menunjukkan penurunan. Jumlah sel Azospirillum dalam arang batok mulai mengalami penurunan pada hari ke-7 dan terus menurun dari jumlah awal $10^{5} \mathrm{spk} \mathrm{ml}^{-1}$ menjadi $10^{4} \mathrm{spk} \mathrm{g}^{-1}$ hingga hari ke 70 pada bahan pembawa arang batok dan zeolit (Tabel 2). Hal yang sama juga terjadi pada viabilitas Azospirillum dalam bahan pembawa gambut dan kompos yaitu jumlah sel menurun dari $10^{7} \mathrm{spk} \mathrm{ml}^{-1}$ menjadi $10^{5} \mathrm{spk} \mathrm{g}^{-1}$ hingga hari ke-70 (Tabel 3).

Tabel 2. Viabilitas inokulan Azospirillum dalam bahan pembawa arang batok dan zeolit steril menggunakan iradiasi sinar gamma Co-60, MBE dan autoklaf pada suhu kamar selama masa penyimpanan 70 hari

\begin{tabular}{|c|c|c|c|c|c|}
\hline \multirow{2}{*}{ Bahan Pembawa } & \multirow{2}{*}{ Metode Sterilisasi } & \multicolumn{4}{|c|}{ Masa Penyimpanan (hari) } \\
\hline & & 7 & 21 & 42 & 70 \\
\hline \multirow{4}{*}{ Arang Batok } & & & .........spk & awa ......... & \\
\hline & MBE & $4.00 \times 10^{5}$ & $1.50 \times 10^{5}$ & $1.50 \times 10^{4}$ & $7.00 \times 10^{4}$ \\
\hline & $\mathrm{Co}-60$ & $3.00 \times 10^{5}$ & $2.00 \times 10^{5}$ & $7.00 \times 10^{4}$ & $7.00 \times 10^{4}$ \\
\hline & Autoklaf & $3.50 \times 10^{6}$ & $4.00 \times 10^{5}$ & $1.10 \times 10^{5}$ & $1.10 \times 10^{5}$ \\
\hline \multirow{3}{*}{ Zeolit } & MBE & $3.50 \times 10^{6}$ & $3.50 \times 10^{6}$ & $3.00 \times 10^{5}$ & $3.50 \times 10^{6}$ \\
\hline & $\mathrm{C} 0-60$ & $1.10 \times 10^{6}$ & $7.50 \times 10^{4}$ & $7.50 \times 10^{4}$ & $4.00 \times 10^{5}$ \\
\hline & Autoklaf & $2.00 \times 10^{5}$ & $1.10 \times 10^{5}$ & $1.50 \times 10^{4}$ & $4.00 \times 10^{5}$ \\
\hline
\end{tabular}

Keterangan : Jumlah sel awal $4.50 \times 10^{5} \mathrm{spk} \mathrm{ml}^{-1} ;(+)$ : kenaikan jumlah sel 
Tabel 3. Viabilitas inokulan Azospirillum dalam bahan pembawa gambut dan kompos steril menggunakan iradiasi sinar gamma Co-60, MBE dan autoklaf pada suhu kamar selama masa penyimpanan 70 hari

\begin{tabular}{|c|c|c|c|c|c|}
\hline \multirow{2}{*}{ Bahan Pembawa } & \multirow{2}{*}{ Metode Sterilisasi } & \multicolumn{4}{|c|}{ Masa Penyimpanan (hari) } \\
\hline & & 7 & 21 & 42 & 70 \\
\hline \multirow{4}{*}{ Gambut } & & & $\ldots \ldots$ spk g ${ }^{-1}$ & wa ............. & \\
\hline & MBE & $3.00 \times 10^{6}$ & $4.50 \times 10^{6}$ & $3.00 \times 10^{5}$ & $1.40 \times 10^{5}$ \\
\hline & Co-60 & $1.30 \times 10^{6}$ & $6.00 \times 10^{6}$ & $2.00 \times 10^{5}$ & $3.00 \times 10^{5}$ \\
\hline & Autoklaf & $2.00 \times 10^{6}$ & $1.50 \times 10^{5}$ & $1.60 \times 10^{5}$ & $7.00 \times 10^{5}$ \\
\hline \multirow{3}{*}{ Kompos } & MBE & $2.00 \times 10^{7}$ & $1.10 \times 10^{7}$ & $1.10 \times 10^{7}$ & $1.50 \times 10^{6}$ \\
\hline & Co-60 & $1.15 \times 10^{7}$ & $4.50 \times 10^{6}$ & $4.50 \times 10^{6}$ & $2.00 \times 10^{6}$ \\
\hline & Autoklaf & $1.10 \times 10^{8}$ & $1.10 \times 10^{7}$ & $4.50 \times 10^{6}$ & $2.50 \times 10^{6}$ \\
\hline
\end{tabular}

Keterangan : Jumlah sel awal $1.40 \times 10^{7} \mathrm{spk} \mathrm{ml}^{-1} ;(+)$ : kenaikan jumlah sel

Jumlah sel Azospirillum pada hari ke-7 dalam bahan pembawa arang batok sterilisasi autoklaf lebih tinggi dibandingkan dalam arang batok sterilisasi iradiasi Sinar Gamma Co-60 dan MBE. Sebaliknya dengan zeolit, jumlah sel Azospirillum dalam zeolit steril iradiasi Sinar Gamma Co-60 dan MBE lebih tinggi dibandingkan dengan zeolit steril autoklaf. Hal tersebut dapat disebabkan oleh adaptasi awal Azospirillum terhadap lingkungan bahan pembawa. Menurut Alexander (1977), Azospirillum hidup pada lingkungan dengan $\mathrm{pH}$ 6.8-7.9.

Efek yang ditimbulkan dari penggunaan metode sterilisasi iradiasi Sinar Gamma Co-60 dan MBE adalah kenaikan $\mathrm{pH}$ terhadap bahan yang diradiasi. Kenaikan $\mathrm{pH}$ tersebut umumnya terjadi pada tanah terutama tanah yang lembab (Lotrario et al., 1995; Tuominen et al., 1994).

Nilai $\mathrm{pH}$ arang batok dan zeolit masing-masing 8.4 dan 5.8, sedangkan nilai $\mathrm{pH}$ gambut dan kompos masingmasing 4.2 dan 7.3. Kenaikan nilai $\mathrm{pH}$ arang batok dan gambut akibat sterilisasi iradiasi Sinar Gamma Co-60 dan MBE kurang mendukung ketahanan hidup Azospirillum sehingga jumlah sel pada hari ke-7 lebih rendah dibandingkan jumlah sel dalam arang batok steril autoklaf. Sebaliknya kenaikan nilai $\mathrm{pH}$ pada zeolit dan kompos steril iradiasi Sinar Gamma Co-60 dan MBE menyebabkan lingkungan hidup Azospirillum semakin mendukung sehingga jumlah sel pada hari ke-7 lebih tinggi dibandingkan jumlah sel dalam zeolit steril autoklaf.

Persentase penurunan jumlah sel Azospirillum yang paling besar adalah pada bahan gambut steril MBE yaitu sebesar $99.0 \%$ dan yang paling kecil pada bahan zeolit steril iradiasi Sinar Gamma Co-60 dan autoklaf yaitu $11.1 \%$. Selain penurunan jumlah sel, terdapat juga kenaikan jumlah sel Azospirillum yaitu pada bahan zeolit steril MBE hingga akhir penyimpanan hari ke-70. Hal ini diduga disebabkan oleh kondisi lingkungan pada bahan tersebut optimum untuk Azospirillum bertumbuh.

Penurunan viabilitas Azospirillum dengan berbagai metode sterilisasi dalam arang batok, zeolit, gambut dan kompos dapat dilihat pada Gambar 1. Penggunaan sterilisasi iradiasi Sinar Gamma Co-60, MBE dan autoklaf menunjukkan viabilitas mikrob hingga hari ke-70 masih relatif tinggi dalam keempat bahan pembawa walaupun terjadi penurunan dari jumlah sel awal yang dimasukkan ke dalam bahan pembawa. Namun walaupun demikian, zeolit lebih mampu mempertahankan viabilitas Azospirillum hingga masa penyimpanan 70 hari dibandingkan dengan arang batok, gambut dan kompos. Hal tersebut ditandai dengan persentase penurunan jumlah sel Azospirillum pada bahan pembawa zeolit yang paling kecil diantara ketiga bahan pembawa lainnya.

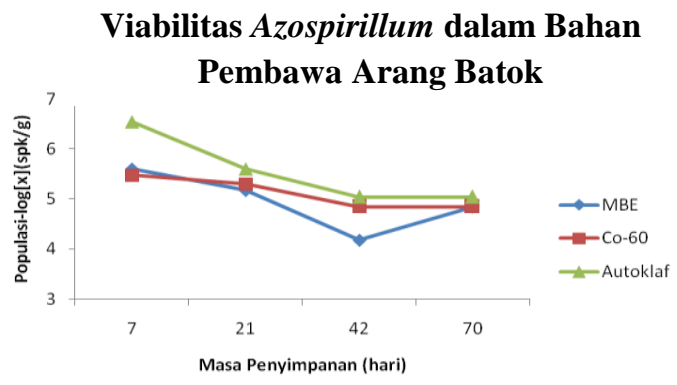

Viabilitas Azospirillum dalam Bahan Pembawa Kompos

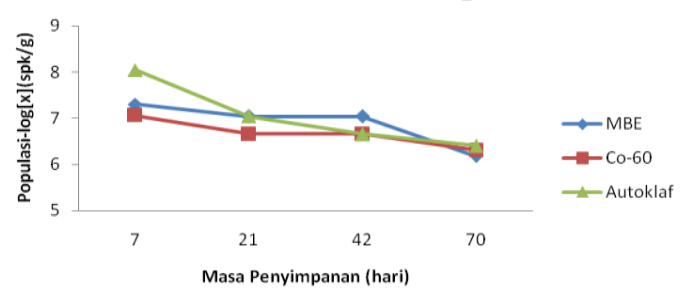

Viabilitas Azospirillum dalam Bahan Pembawa Zeolit

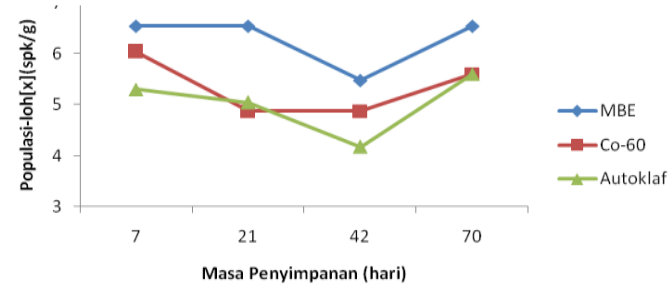

Viabilitas Azospirillum dalam Bahan Pembawa Gambut

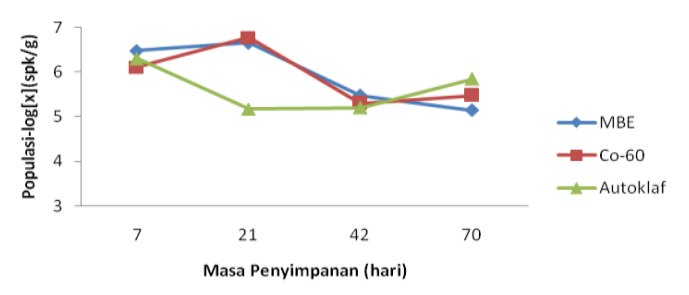

Gambar 1. Populasi Azospirillum dalam bahan pembawa arang batok, zeolit, gambut dan kompos steril selama masa penyimpanan 70 hari 


\section{Uji Viabilitas Azotobacter dalam Bahan Pembawa Steril}

Viabilitas Azotobacter dalam bahan pembawa arang batok, zeolit dan gambut mengalami penurunan selama masa penyimpanan 70 hari (Tabel 4), sedangkan viabilitas Azotobacter dalam bahan pembawa kompos mengalami peningkatan selama masa penyimpanan (Tabel 5). Pada umumnya Azotobacter tumbuh optimum pada keadaan $\mathrm{pH}$ > 6.0 (Alexander, 1977).
Persentase penurunan jumlah sel Azotobacter yang paling besar adalah pada bahan arang batok steril iradiasi Sinar Gamma Co-60 yaitu sebesar 99.1\%. Penurunan viabilitas sel Azotobacter dalam bahan pembawa arang batok, zeolit dan gambut memiliki rata-rata kisaran lebih dari $90 \%$. Hal tersebut diduga karena Azotobacter tidak mampu mempertahankan hidupnya dalam ketiga bahan pembawa tersebut serta keadaan lingkungan bahan pembawa yang tidak optimum untuk mendukung kehidupan Azotobacter.

Tabel 4. Viabilitas inokulan Azotobacter dalam bahan pembawa arang batok dan zeolit steril menggunakan iradiasi sinar gamma Co-60, MBE dan autoklaf pada suhu kamar selama masa penyimpanan 70 hari

\begin{tabular}{|c|c|c|c|c|c|}
\hline \multirow{2}{*}{ Bahan Pembawa } & \multirow{2}{*}{ Metode Sterilisasi } & \multicolumn{4}{|c|}{ Masa Penyimpanan (hari) } \\
\hline & & 7 & 21 & 42 & 70 \\
\hline \multirow{4}{*}{ Arang Batok } & & & $\ldots$ spk g & awa . & \\
\hline & $\mathrm{MBE}$ & $2.12 \times 10^{9}$ & $5.08 \times 10^{8}$ & $3.33 \times 10^{8}$ & $1.65 \times 10^{8}$ \\
\hline & Co-60 & $2.18 \times 10^{9}$ & $7.61 \times 10^{8}$ & $3.22 \times 10^{8}$ & $4.41 \times 10^{7}$ \\
\hline & Autoklaf & $8.91 \times 10^{8}$ & $8.85 \times 10^{8}$ & $2.42 \times 10^{8}$ & $1.92 \times 10^{8}$ \\
\hline \multirow{3}{*}{ Zeolit } & MBE & $2.45 \times 10^{9}$ & $6.96 \times 10^{8}$ & $7.42 \times 10^{8}$ & $4.58 \times 10^{8}$ \\
\hline & Co-60 & $2.36 \times 10^{9}$ & $5.15 \times 10^{8}$ & $3.12 \times 10^{8}$ & $2.30 \times 10^{8}$ \\
\hline & Autoklaf & $1.34 \times 10^{9}$ & $1.57 \times 10^{9}$ & $9.11 \times 10^{8}$ & $5.80 \times 10^{7}$ \\
\hline
\end{tabular}

Keterangan : Jumlah sel awal $4.78 \times 10^{9} \mathrm{spk} \mathrm{ml}^{-1}$

Tabel 5. Viabilitas inokulan Azotobacter dalam bahan pembawa gambut dan kompos steril menggunakan iradiasi sinar gamma Co-60, MBE dan autoklaf pada suhu kamar selama masa penyimpanan 70 hari

\begin{tabular}{|c|c|c|c|c|c|}
\hline \multirow{2}{*}{ Bahan Pembawa } & \multirow{2}{*}{ Metode Sterilisasi } & \multicolumn{4}{|c|}{ Masa Penyimpanan (hari) } \\
\hline & & 7 & 21 & 42 & 70 \\
\hline \multirow{4}{*}{ Gambut } & & & $\ldots \mathrm{spk} \mathrm{g}^{-1} \mathrm{~b}$ & va & \\
\hline & MBE & $1.47 \times 10^{7}$ & $1.15 \times 10^{9}$ & $4.25 \times 10^{9}$ & $2.20 \times 10^{7}$ \\
\hline & Co-60 & $7.70 \times 10^{8}$ & $3.58 \times 10^{9}$ & $1.47 \times 10^{9}$ & $1.60 \times 10^{7}$ \\
\hline & Autoklaf & $3.57 \times 10^{9}$ & $6.34 \times 10^{9}$ & $2.48 \times 10^{9}$ & $3.38 \times 10^{7}$ \\
\hline \multirow[t]{2}{*}{ Kompos } & Co-60 & $1.59 \times 10^{10}$ & $7.18 \times 10^{9}$ & $5.05 \times 10^{9}$ & $8.56 \times 10^{9}$ \\
\hline & Autoklaf & $2.05 \times 10^{9}$ & $5.79 \times 10^{9}$ & $2.98 \times 10^{9}$ & $5.65 \times 10^{9}$ \\
\hline
\end{tabular}

Keterangan : Jumlah sel awal $9.56 \times 10^{8} \mathrm{spk} \mathrm{ml}^{-1} ;(+)$ : kenaikan jumlah sel

Kenaikan jumlah sel Azotobacter dalam bahan pembawa kompos hingga masa penyimpanan 70 hari diduga disebabkan oleh kompos merupakan bahan yang lebih optimum untuk Azotobacter bertumbuh. Hal tersebut sesuai dengan penelitian Lasrin (1997) yang menyebutkan bahwa populasi Azotobacter mengalami peningkatan dalam bahan kompos hingga masa penyimpanan 10 minggu pada suhu $28^{\circ} \mathrm{C}$.
Viabilitas Azotobacter dalam arang batok dan zeolit yang disterilisasi dengan berbagai metode menunjukkan hasil yang hampir seragam (Gambar 2). Hal tersebut menunjukkan bahwa viabilitas Azotobacter tidak terlalu banyak dipertahankan melalui berbagai metode sterilisasi pada bahan pembawa arang batok, zeolit dan gambut. 

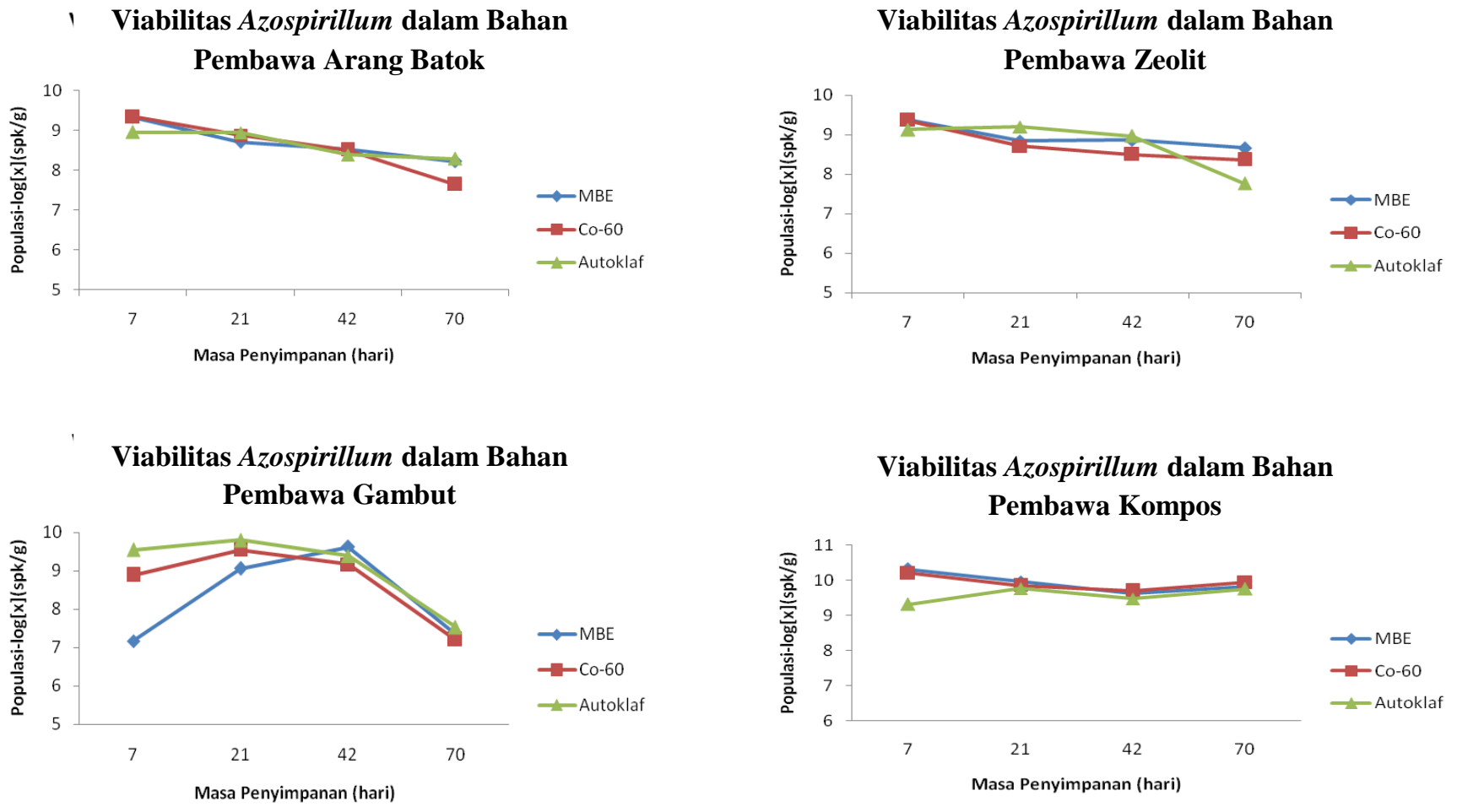

Gambar 2. Populasi Azotobacter dalam bahan pembawa arang batok, zeolit, gambut dan kompos steril selama masa penyimpanan 70 hari

\section{Uji Viabilitas Fungi Pelarut Fosfat dalam Bahan Pembawa Steril}

Persentase penurunan jumlah sel Fungi Pelarut Fosfat (FPF) dari jumlah sel awal hingga masa penyimpanan 70 hari ditunjukkan oleh Tabel 6 dan 7 .
Persentase penurunan jumlah sel FPF yang paling besar adalah pada bahan arang batok steril autoklaf dan bahan kompos iradiasi Sinar Gamma Co-60 yaitu sebesar 99.8\% dan penurunan paling kecil adalah pada bahan kompos steril autoklaf yaitu $45.8 \%$.

Tabel 6. Viabilitas inokulan fungi pelarut fosfat dalam bahan pembawa arang batok dan zeolit steril menggunakan iradiasi sinar gamma Co60, MBE dan autoklaf pada suhu kamar selama masa penyimpanan 70 hari

\begin{tabular}{|c|c|c|c|c|c|}
\hline \multirow{2}{*}{ Bahan Pembawa } & \multirow{2}{*}{ Metode Sterilisasi } & \multicolumn{4}{|c|}{ Masa Penyimpanan (hari) } \\
\hline & & 7 & 21 & 42 & 70 \\
\hline \multirow{4}{*}{ Arang Batok } & & & .... spk g- & awa ........... & \\
\hline & MBE & $7.77 \times 10^{8}$ & $1.83 \times 10^{8}$ & $1.83 \times 10^{8}$ & $5.61 \times 10^{7}$ \\
\hline & $\mathrm{Co}-60$ & $3.64 \times 10^{9}$ & $6.66 \times 10^{8}$ & $1.66 \times 10^{8}$ & $3.33 \times 10^{7}$ \\
\hline & Autoklaf & $2.52 \times 10^{9}$ & $3.83 \times 10^{7}$ & $3.30 \times 10^{6}$ & $8.33 \times 10^{5}$ \\
\hline \multirow{3}{*}{ Zeolit } & MBE & $3.17 \times 10^{8}$ & $2.03 \times 10^{8}$ & $1.68 \times 10^{8}$ & $2.83 \times 10^{7}$ \\
\hline & Co-60 & $7.30 \times 10^{8}$ & $1.66 \times 10^{8}$ & $2.05 \times 10^{8}$ & $8.00 \times 10^{7}$ \\
\hline & Autoklaf & $1.49 \times 10^{9}$ & $1.66 \times 10^{7}$ & $1.21 \times 10^{7}$ & $6.66 \times 10^{6}$ \\
\hline
\end{tabular}

Keterangan : Jumlah sel awal $3.44 \times 10^{8} \mathrm{spk} \mathrm{ml}^{-1}$

Tabel 7. Viabilitas inokulan fungi pelarut fosfat dalam bahan pembawa gambut dan kompos steril menggunakan iradiasi sinar gamma Co-60, MBE dan autoklaf pada suhu kamar selama masa penyimpanan 70 hari

\begin{tabular}{|c|c|c|c|c|c|}
\hline \multirow{2}{*}{ Bahan Pembawa } & \multirow{2}{*}{ Metode Sterilisasi } & \multicolumn{4}{|c|}{ Masa Penyimpanan (hari) } \\
\hline & & 7 & 21 & 42 & 70 \\
\hline \multirow{4}{*}{ Gambut } & & & .. spk $\xi$ & awa. & \\
\hline & MBE & $3.00 \times 10^{5}$ & $3.60 \times 10^{7}$ & $2.00 \times 10^{7}$ & $7.67 \times 10^{6}$ \\
\hline & Co-60 & $6.40 \times 10^{6}$ & $3.89 \times 10^{7}$ & $2.50 \times 10^{6}$ & $1.43 \times 10^{7}$ \\
\hline & Autoklaf & $5.70 \times 10^{6}$ & $5.60 \times 10^{7}$ & $1.00 \times 10^{6}$ & $9.62 \times 10^{6}$ \\
\hline \multirow{3}{*}{ Kompos } & MBE & $1.29 \times 10^{7}$ & $1.10 \times 10^{8}$ & $6.80 \times 10^{7}$ & $3.33 \times 10^{6}$ \\
\hline & Co-60 & $1.62 \times 10^{7}$ & $5.00 \times 10^{6}$ & $1.00 \times 10^{6}$ & $1.67 \times 10^{5}$ \\
\hline & Autoklaf & $2.00 \times 10^{7}$ & $6.70 \times 10^{7}$ & $1.20 \times 10^{8}$ & $3.73 \times 10^{7}$ \\
\hline
\end{tabular}

Keterangan : Jumlah sel awal $6.88 \times 10^{7} \mathrm{spk} \mathrm{ml}^{-1}$ 
Metode sterilisasi autoklaf mengakibatkan penurunan jumlah sel FPF yang paling besar pada bahan pembawa arang batok dan zeolit. Hal tersebut diduga disebabkan oleh keracunan dari kelarutan unsur akibat proses autoklaf sehingga FPF tidak mampu mempertahankan hidupnya. Metode sterilisasi iradiasi Sinar Gamma Co-60 juga mengakibatkan penurunan jumlah sel FPF pada bahan pembawa kompos. Hal tersebut dapat diduga disebabkan oleh kurang mendukungnya kondisi lingkungan bahan kompos setelah disterilisasi menggunakan iradiasi Sinar Gamma Co-60. Penggunaan sterilisasi iradiasi Sinar Gamma Co-60 pada dosis $50 \mathrm{kGy}$ mengubah sifat kimia tanah yaitu meningkatnya $\mathrm{NH}_{4}$ (Bowen dan Cawse, 1964; Tuominen et al., 1994), fosfor, mangan dan kalium (Bowen dan Cawse, 1964) serta kenaikan $\mathrm{pH}$ yang umumnya terjadi pada tanah lembab (Lotrario et al., 1995; Tuominen et al., 1994). Menurut Waksman dan Starkey (1981), pertumbuhan FPF optimum pada keadaan masam $\mathrm{pH} 5.0$ - 5.5. Hal tersebut dapat menjelaskan mengapa viabilitas FPF dalam kompos steril mengalami penurunan jumlah sel yang paling besar hingga hari ke 70.
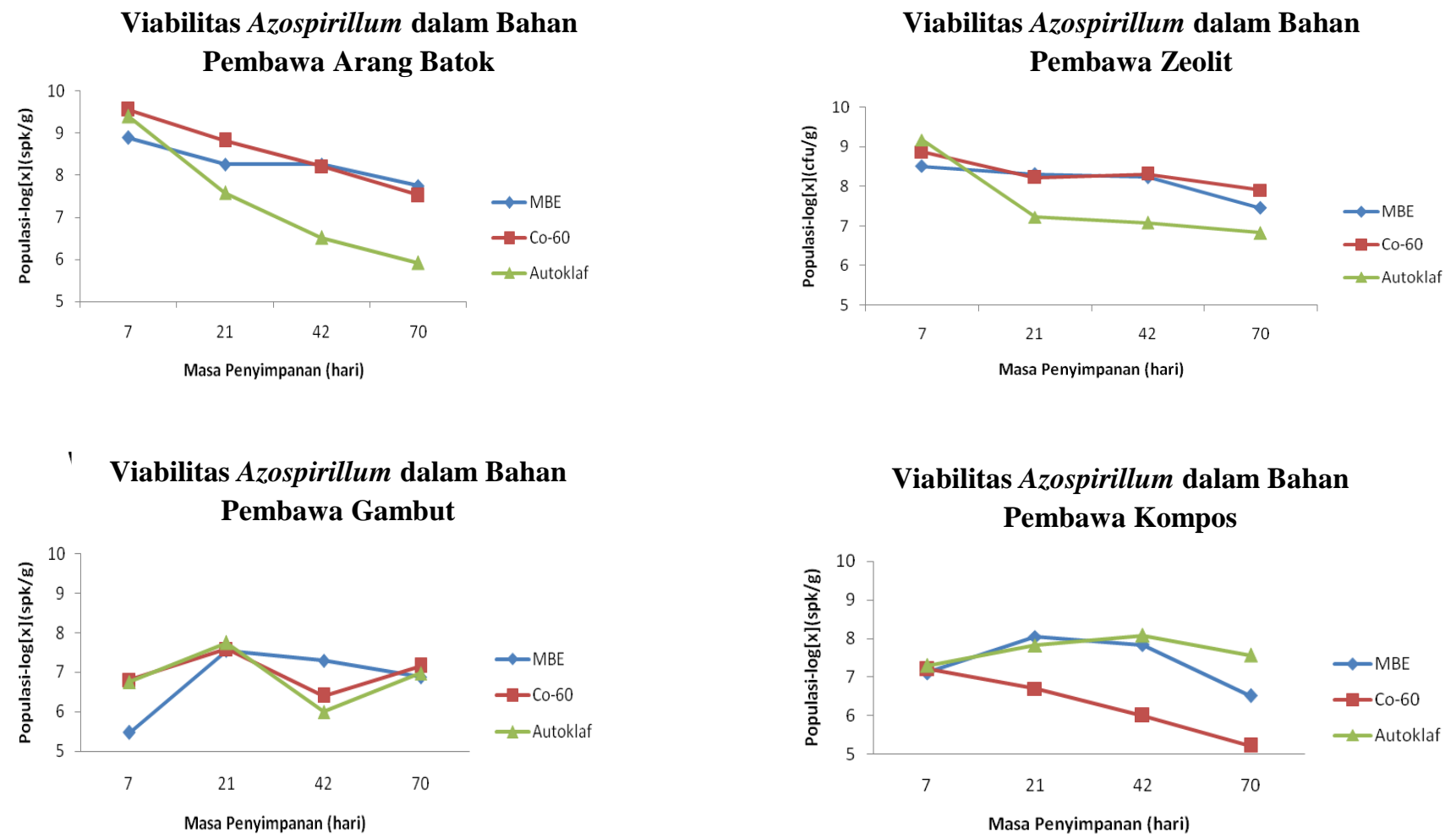

Gambar 3. Populasi Fungi Pelarut Fosfat dalam bahan pembawa arang batok, zeolit, gambut dan kompos steril selama masa penyimpanan 70 hari

Pemilihan bahan pembawa serta metode sterilisasi yang digunakan dapat mempengaruhi kelangsungan hidup mikrob inokulan. Bahan pembawa zeolit memberikan hasil yang lebih baik dalam mempertahankan viabilitas inokulan Azospirillum, Azotobacter dan FPF dibandingkan dengan arang batok hingga masa penyimpanan 70 hari. Sedangkan metode sterilisasi yang lebih baik dalam mempertahankan viabilitas inokulan adalah iradiasi Sinar Gamma Co-60.

Bahan pembawa zeolit yang disterilkan dengan metode iradiasi Sinar Gamma Co-60 dan autoklaf dengan inokulan Azospirillum memberikan hasil yang terbaik dalam uji viabilitas dengan persentase penurunan jumlah sel sebesar $11.1 \%$. Namun penggunaan metode sterilisasi autoklaf terhadap bahan pembawa arang batok menyebabkan penurunan jumlah sel inokulan FPF sebesar 99.8\%. Penggunaan metode sterilisasi iradiasi Sinar Gamma Co-60 terhadap kompos juga menyebabkan penurunan jumlah sel inokulan FPF sebesar $99.8 \%$ sehingga dapat dikatakan autoklaf dan iradiasi Sinar Gamma Co-60 bukanlah metode sterilisasi yang terbaik.

Masing-masing inokulan memberikan hasil uji viabilitas yang berbeda terhadap metode sterilisasi yang digunakan terhadap bahan pembawa. Hal ini diduga disebabkan oleh perubahan kondisi bahan pembawa yang merupakan lingkungan hidup mikrob inokulan akibat proses sterilisasi. Penggunaan sterilisasi iradiasi Sinar Gamma Co-60 pada dosis $50 \mathrm{kGy}$ mengubah sifat kimia tanah yaitu meningkatnya $\mathrm{NH}_{4}$ (Bowen dan Cawse, 1964; Tuominen et al., 1994), fosfor, mangan dan kalium (Bowen dan Cawse, 1964) serta kenaikan $\mathrm{pH}$ yang umumnya terjadi pada tanah lembab (Lotrario et al., 1995; Tuominen et al., 1994).

Penggunaan sterilisasi autoklaf dengan intensitas tertentu dapat meningkatkan kelarutan $\mathrm{Fe}, \mathrm{Mn}$ dan $\mathrm{Zn}$ yang tinggi sehingga dapat meracuni mikob yang ada di dalamnya (Toharisman, 1989). Proses autoklaf juga dapat 
menyebabkan penurunan nilai $\mathrm{pH}$ hingga mencapai 0.2 unit (Skipper dan Westermann, 1973).

\section{KESIMPULAN}

Bahan pembawa zeolit memberikan hasil yang lebih baik dalam mempertahankan viabilitas inokulan Azospirillum, Azotobacter dan Fungi Pelarut Fosfat (FPF) hingga masa penyimpanan 70 hari. Selanjutnya, metode sterilisasi yang lebih baik dalam mempertahankan viabilitas inokulan adalah autoklaf dan iradiasi Sinar Gamma Co-60 sedangkan metode EBM tidak efektif menurunkan populasi mikroba dalam bahan pembawa. Bahan pembawa zeolit yang disterilkan dengan metode iradiasi Sinar Gamma Co60 dan autoklaf dengan inokulan Azospirillum memberikan hasil yang terbaik dalam uji viabilitas dengan persentase penurunan jumlah sel sebesar $11.1 \%$.

Penggunaan metode sterilisasi autoklaf terhadap bahan pembawa arang batok menyebabkan penurunan jumlah sel inokulan FPF sebesar 99.8\%. Penggunaan metode sterilisasi iradiasi Sinar Gamma Co-60 terhadap kompos juga menyebabkan penurunan jumlah sel inokulan FPF sebesar $99.8 \%$ sehingga dapat dikatakan autoklaf dan iradiasi Sinar Gamma Co-60 bukanlah metode sterilisasi yang terbaik.

\section{SARAN}

Perlu dilakukan kelanjutan uji viabilitas inokulan hingga masa penyimpanan satu tahun serta pengujian efektivitas mikrob dengan pengaplikasian pada tanaman sehingga kualitas mikrob dalam bahan pembawa dapat diketahui. Pengujian lanjut sterilisasi bahan pembawa juga perlu dilakukan untuk mengetahui batas masa penyimpanan.

\section{DAFTAR PUSTAKA}

Alexander, M. 1977. Introduction to Soil Microbiology. 2nd Ed. John Wiley and Sons. New York.

Bowen, H. J. M. and P. A. Cawse. 1964. Some effects of gamma radiation on the composition of the soil solution and soil organic matter. Soil Sci., 98: 358361 .

Hidayati, N. 2009. Efektivitas Pupuk Hayati pada Berbagai Lama Simpan Terhadap Pertumbuhan Tanaman Padi (Oryza sativa) dan Jagung (Zea mays) [skripsi].
Fakultas Matematika dan Ilmu Pengetahuan Alam. Institut Pertanian Bogor.

Hilmy, N. 1980. Penetapan Dosis Sterilisasi dan Pasteurisasi Radiasi. Pusat Aplikasi Isotop dan Radiasi. Jakarta.

Kume, T. 2005. Radiation Sterilization of Carrier. FNCA Biofertilizer Project Technical meeting on Sterilization of Carrier by Irradiation. Tokyo.

Lasrin, H. 1997. Ketahanan Hidup Azotobacter Penambat Nitrogen pada Berbagai Bahan Pembawa Serta Pengaruhnya Terhadap Pertumbuhan Tanaman Jagung (Zea Mays). Skripsi Departemen Ilmu Tanah, Fakultas Pertanian IPB.

Lotrario, J. B., B. J. Stuart., T. Lam., R. R. Arands, and D. S. Kosson. 1995. Effects of sterilization methods on the physical characteristics of soil: implications for sorption isotherm analyses. Environ. Contam. Toxicol., 54: 668-675.

Rao, N. S. 1982. Biofertilizers in Agriculture. Oxford \& IBH Publishing Co. Oxford.

Skipper, H. D. dan D. T. Westermann. 1973. Comperative effects propylene oxide, sodium azide and autoclaving on selected soil properties. Soil Biol. Biochem., 5: 409-414.

Toharisman, A. 1989. Evaluasi berbagai Metode Sterilisasi Tanah dan Pengaruh Sterilisasi Autoklaf terhadap Beberapa Sifat Tanah dan Pertumbuhan Tanaman Kedelai dan Jagung [skripsi]. Jurusan Tanah. Fakultas Pertanian. Institut Pertanian Bogor.

Tombe, M. 2008. Sekilas Pupuk Hayati. Direktorat Perbenihan dan Sarana Produksi. http://dasar2ilmutanah.blogspot.com.

Tuominen, L., T. Kairesalo., and H. Hartikainen. 1994. Comparison of methods for inhibiting bacterial activity in sediment. Appl. Environ. Microbiol., 60: 3454-3457.

Van Dyke, M. I. and J. I. Prosser. 2000. Enhanced survival of Pseudomonas fluorescens in soil following estabilishment of inoculum in a sterile soil carrier. Soil Biol. Biochem., 32: 1377-1382.

Waksman, S. A. and R. L. Starkey. 1981. The Soil and The Microbe. John Wiley and Sons, Inc. New York. 